\title{
AFFECT IN EXPRESSIVE SPEECH ACTS BY THE JUDGES OF THE VOICE UK VERSUS THE VOICE VIETNAM
}

\author{
Nguyen Quang Ngoan*, Le Huu Loc \\ Department of Foreign Languages, Quy Nhon University \\ 170 An Duong Vuong, Quy Nhon, Binh Dinh, Vietnam \\ Received 10 July 2019 \\ Revised 1 August 2019; Accepted 22 December 2019
}

\begin{abstract}
Appraisal Theory by Martin and White (2005) has increasingly claimed its potential in discourse analysis studies, highlighting the speakers' and writers' evaluations of people, entities, and events. This paper adopts Martin and White's Appraisal framework for the purpose of determining the Affect in the expressives made by the judges of the two reality shows, The Voice UK versus The Voice Vietnam. Specifically, the research addresses itself to discovering which Affect resources are used in the expressive acts by the judges and indicating the resemblances and discrepancies in employing those resources in the expressives by the two groups of judges. The results reveal that all of the sub-types of Affect were found in the two data sets. Besides, the Affect resources in the two languages share a variety of similarities in terms of their frequency, realization strategies, and polarities. The study can be the reference for learners of English and Vietnamese in passing their remarks in daily communication.
\end{abstract}

Keywords: Appraisal, affect, attitude, expressives, judges

\section{Introduction}

The favorable outcome of many reality shows results not only from the reputation and unique talents of the judges but also from the language they use. Indeed, the comments given by the judges have a vital part to play as they encourage the audience to evaluate and vote for excellent contestants and enable the candidates to be aware of their shortcomings, foster their spirit for the next rounds through appropriate incitement. Apart from that, the spectators are allowed to carry out objective and adequate assessments of the judges, particularly regarding the attitudinal ones. Passing remarks, accordingly, can be considered the art of conversation because this

* Corresponding author. Tel.: 84-911308279

Email: nguyenquangngoan@qnu.edu.vn practice can leave the viewers with favorable impressions about the judges, contributing to enhancing the judges' prestige.

Besides, if appropriately treated, the judges' language can serve as precious, genuine resources for individuals who research, teach, and learn the language. This justifies the fact that these linguistic resources have become an intriguing realm of research. Master's theses on this topic were conducted, namely the one by T. N. Vo (2017) on expressive speech acts in judges' comments in America's Got Talent versus Vietnam's Got Talent, Bui (2018) on transitivity in comments given by the judges in American Master-Chef and Vietnam's Master-Chef, and T. T. Nguyen (2018) on attitudinal resources in comments by judges in American Idol and Vietnam's Idol. 
With respect to Appraisal Theory, D. D. Vo (2011), in his doctoral thesis, studied journalistic voices operating in English Vietnamese hard news reports in the light of Appraisal and the system of voices. Regarding the spoken language, T. Ngo (2013) investigated the discrepancies in the application of Appraisal resources, especially Attitude and Graduation, by Vietnamese students in Australia when partaking in English and Vietnamese oral discussions. T. T. H. Tran (2018) successfully defended her doctoral thesis which revolved around the language of evaluation by the judges in some Vietnamese entertaining programs, with reference being made to the English language.

Besides, quite a large number of master's studies on the attitudinal aspect have been carried out, investigating a wide range of discourse types, ranging from American leaders' speeches (T. N. H. Vo (2014), Le (2017), T. T. T. Tran (2017)), travel advertisements (T. H. Nguyen, 2015), travellers' holiday reviews (K. L. Nguyen, 2017), readers' opinions (T. K. T. Vo, 2017), letters of complaint (T. B. C. Le, 2017), news about environment (A. Q. N. Ngo, 2017), advertising slogans (T. M. N. Nguyen, 2017), film reviews (Phan, 2017), to love song lyrics ( T. N. Nguyen, 2018).

Apart from that, Appraisal Theory was applied in the research of childbirth narratives (Page, 2003), high- and lowrated English argumentative essays by EFL students in two Chinese universities (Liu, 2013), English song discourses (Li, 2016), critical reading in teaching English at colleges (Ruo-mei, 2016), English novel discourse (Hadidi \& MohammadbagheriParvin, 2015) or President Xi's remarks at the press conference (Zhang, 2018).
It can be seen that Appraisal Theory and Speech Act Theory are of great interest to researchers. However, a study of the Attitudinal evaluation via the speech acts appears to be an untouched issue. Searl and Vanderveken (1985) (as cited in Ronan, 2015, p. 30) hints at the close relationship between the expressives and Appraisal Theory by stating that expressive speech act verbs "usually express good or bad evaluations, and they are hearer centered". As a result, this paper strives for applying Appraisal framework, focusing on the system of Attitude, to gain an insight into the use of Affect resources in the expressives made by the coaches in the popular TV series, The Voice. In detail, the study addresses itself to answering the questions of (1) which Affect resources are used and how often they are used in the EUJs versus EVJs and (2) what the similarities and differences of the Attitudinal resources in the EUJs versus those in EVJs are.

The expressives surveyed, specifically, 176 expressives by the Vietnamese judges (EVJs) and 178 by the English judges (EUJs), were yielded from the judges' comments in The Voice UK 2018 and The Voice Vietnam 2018.

\section{Theoretical background}

This research makes use of the Appraisal framework, with attention being geared towards one of the Attitudinal sub-systems, Affect. The purpose of this utilization is to identify the Affect resources in expressive speech acts by the two groups of judges, pointing out the similarities and discrepancies regarding the types, strategies and extremes of the Affect values employed.

The theory of speech acts, especially expressive acts, is also reviewed purely for purpose of laying foundations for extracting expressives from the judges comments, which serve as the research data. 


\subsection{Appraisal theory}

According to Ruo-mei (2016, p. 869), the Appraisal framework was originated from Systemic Functional Linguistics, being proposed by an Australian-based group of linguists headed by James R. Martin in the 1990s. White (2015b, p. 1) defines Appraisal as "an approach to exploring, describing and explaining the way language is used to evaluate, to adopt stances, to construct textual personas and to manage interpersonal positionings and relationships."

As Martin and White (2005, pp. 3435) state, Appraisal "is one of three major discourse semantic resources construing interpersonal meaning" accompanied by involvement and negotiation. The Appraisal resources are used "for negotiating our social relationships, by telling our listeners or readers how we feel about things and people (in a word, what our attitudes are)" (Martin \& Rose, 2007, p. 26).

Appraisal can be deemed a comprehensive term indicating language resources by which speakers/writers can offer positive or negative evaluations of people, things, places, events, and states of affairs, exercise interpersonal engagement with listeners/readers in either actual or potential manners, and achieve, to a certain extent, the utterances' intensity and preciseness. ( D. D. Vo, 2011, pp. 28-29). According to Martin and White (2005, pp. 3435), the Appraisal framework encompasses three interacting semantic domains, namely Attitude, Engagement, and Graduation.

Attitude is concerned with "our feelings, including emotional reactions, judgments of behaviors, and evaluation of things" (Martin \& White, 2005, p. 35). Phrased another way, attitude is the resource which is wielded by the speakers or writers to express people's views, positive and negative feeling reactions with participants and offer the assessment of things. The attitudinal evaluations are grouped into three categories, Affect, Judgment, and Appreciation.

Judgment pertains to people's behaviors and actions. According to Martin and White (2005, p. 42), Judgment "deals with attitudes towards behavior, which we admire or criticize, praise or condemn." In other words, the judgment refers to the evaluation of people's behaviors and actions on the basis of ethics and various social standards.

Appreciation is considered the "assessment of artifacts, entities, happenings, and states of affairs by reference to aesthetics and other systems of social valuation" (White, 2015a, p. 2). D. D. Vo (2011, p. 31) affirms, "Appreciation is not always concerned with the evaluation of things, but in many instances, it deals with the aesthetic evaluation of humans." Martin and White $(2005$, p. 56) propose three subtypes in which Appreciation is categorized:

\section{Reaction, Composition, and Valuation.}

Affect can be deemed the "assessment of an emotional reaction" (White, 2015a, p. 2). Specifically, it involves positive and negative emotions about people, things, places, events, and phenomena. To put it another way, Affect is the value by which the writers/speakers indicate emotions. This value expresses not only the writer's feelings but also the souls of those within the text, namely Authorial and Non-Authorial Affect, respectively.

As reviewed by Martin and White (2005, p. 46), Affect can be realized by quality, mental, and behavioral processes, modal adjuncts, and nominalizations. These realizations are clearly illustrated in Table 1. 
Table 1. Grammatical realizations of Affect (Martin \& White, 2005, p. 46)

\begin{tabular}{|l|l|l|}
\hline \multicolumn{1}{|c|}{ Types } & Grammatical realizations & \multicolumn{1}{c|}{ Examples } \\
\hline $\begin{array}{l}\text { affect as 'quality' } \\
\text { - describing participants } \\
\text { - attributed to participants } \\
\text { - manner of processes }\end{array}$ & $\begin{array}{l}\text { Epithet } \\
\text { Attribute } \\
\text { Circumstance }\end{array}$ & $\begin{array}{l}\text { a sad captain } \\
\text { the captain was sad } \\
\text { the captain left sadly }\end{array}$ \\
\hline $\begin{array}{l}\text { affect as 'process' } \\
\text { - affective mental } \\
\text { - affective behavioral }\end{array}$ & Process & $\begin{array}{l}\text { his departure } \text { upset him } \\
\text { he missed them } \\
\text { the captain wept }\end{array}$ \\
\hline $\begin{array}{l}\text { affect as 'comment' } \\
\text { - desiderative }\end{array}$ & Modal Adjunct & sadly, he had to go \\
\hline affect as 'nominalisations' & Subject, Object, ... & fear, joy, sadness, grief, etc. \\
\hline
\end{tabular}

Martin and White (2005, pp. 48-49) categorize Affect into four significant sets, namely Un/Happiness, In/Security, Dis/ Satisfaction, and Dis/ Inclination. Dis/ Inclination group appertain to feelings foregrounding intention rather than reaction, regarding a stimulus that is irrealis. The other three groups are defined as follows:

The un/happiness variable covers emotions concerned with 'affairs of the heart' - sadness, hate, happiness and love; the in/security variable covers feelings concerned with ecosocial well- being - anxiety, fear, confidence, and trust; the dis/satisfaction variable includes emotions related to telos (the pursuit of goals) - ennui, displeasure, curiosity, respect. (Martin \& White, 2005, p. 49)

After years of development, to be more reasonable and comprehensive, the Affect system has gone through modifications put forward by researchers in the field, especially those by Ngo and Unsworth (2015). The adjustments to the Affect system are illustrated in Figure 1.

Figure 1. Changes to the sub-types of Affect

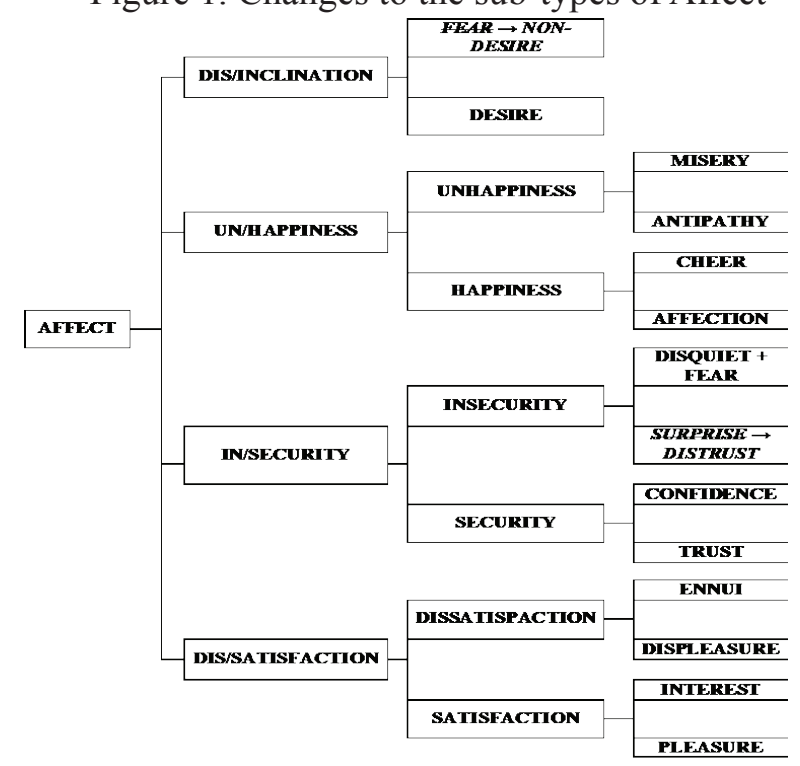

(Ngo \& Unsworth, 2015, p. 12 - based on Martin \& White, 2005) 
Table 2 illustrates the types and sub-types of the Affect system basing on Martin and White (2005) and being refined by Ngo and Unsworth (2015), with examples accompanied.

Table 2. The system of Affect

(Martin \& White, 2005, pp. 48-51) and (Ngo \& Unsworth, 2015)

\begin{tabular}{|c|c|c|}
\hline & Positive & Negative \\
\hline UN/HAPPINESS & $\begin{array}{l}\text { - cheer - laugh, cheerful, ... } \\
\text { - affection - hug, love,... }\end{array}$ & $\begin{array}{l}\text { - misery - cry, sad, ... } \\
\text { - antipathy - abuse, hate, ... }\end{array}$ \\
\hline IN/SECURITY & $\begin{array}{l}\text { - confidence - no pressure, } \\
\text { confident, ... } \\
\text { - trust - optimistic, trusted, ... }\end{array}$ & $\begin{array}{l}\text { - disquiet - stressed, nervous, ... } \\
\text { - distrust - never trust, reluctant, } \\
\text { reserve, suspicion, doubt/doubtful, } \\
\text { hesitate, ... }\end{array}$ \\
\hline DIS/SATISFACTION & $\begin{array}{l}\text { - interest - busy, involved, ... } \\
\text { - pleasure - compliment, pleased, } \\
\text {... }\end{array}$ & $\begin{array}{l}\text { - ennui - yawn, jaded, ... } \\
\text { - displeasure - scold, angry, ... }\end{array}$ \\
\hline DIS/INCLINATION & $\begin{array}{l}\text { desire - miss, long for, yearn for, } \\
\ldots\end{array}$ & $\begin{array}{l}\text { non-desire-ignore, neglect, } \\
\text { reluctant, refuse to, disinclined, ... }\end{array}$ \\
\hline
\end{tabular}

As previously mentioned, the Affect value can be classified into Authorial and NonAuthorial. Through Authorial Affect, "the speaker/writer strongly foregrounds his/her subjective presence in the communicative process" (White, 2015b). In other words, authorial affects pertain to the author's application of the first person to show his/ her direct assessments. In the case of the Non-Authorial Affect, the speakers or writers express feelings of the other individuals. Those are the instances "where it is not the author's emotions which are described but those of other human individuals or groups." (White, 2015b). As a result, he/she makes use of the second and third person to offer evaluations on others' emotions.

According to D. D. Vo (2017, p. 18), through the utilization of Engagement resources, speakers/writers "can adjust and negotiate what White (2001) terms the "arguability" or "dialogic terms" of their utterance." Indeed, Engagement is the language resource signifying voices of the author and the texts. Engagement is of two types, Monogloss and Heterogloss.

Graduation can be seen as "the amplification of both Attitude and the degree of Engagement" (Ngo \& Unsworth, 2015, p. 3). As stated by Martin and White (2005, p. 135), Graduation is concerned with "upscaling and down-scaling."

\subsection{Expressive speech acts}

According to Yule (1996, p. 48), speech acts can be defined as "actions performed via utterances," and they are attached "more specific labels, such as apologies, complaints, compliments, invitations, promises, or requests." He classifies speech acts into locutionary acts, illocutionary acts, and perlocutionary acts. Expressive is one of five illocutionary speech acts, together with declarations, representatives, directives, and commissives.

"Expressives are those kinds of speech acts that state what the speaker feels. They express psychological states and can be statements of pleasure, pain, likes, dislikes, joy, or sorrow". (Yule, 1996, p. 53). Searle (1976, p. 12) asserts that expressives "express the psychological state specified in the sincerity condition about a state of affairs specified in the propositional content." There are many 
ways by which the kinds of expressive acts are categorized, especially those by Austin (1962), Searle (1976), Bach and Harnish (1979), Norrick (1978), and Guiraud, Longin, Lorini, Pesty, and Rivière (2011). The current study employs the taxonomy of expressives suggested by Norrick (1978) as the framework for extracting expressive speech acts made by the judges from their comments, with further reference to the kinds of categorization mentioned.

As Norrick (1978, pp. 284-291) suggests, expressive illocutionary acts can be grouped into apologizing, thanking, congratulating, condoling, deploring, lamenting, welcoming, forgiving, boasting. Apologizing is used to make peace with the people we have hurt, to get rid of the blame, to express regrets, and to trigger acts of forgiving, and to be relieved of fault. In terms of thanking, the speaker would like to acknowledge the benefit gained from the actions of the addressee. As for congratulating, it concerns conveying the speaker's pleasure, pride, or giving encouragements. Regarding condoling, it is similar to congratulating in terms of sharing addressee's experience and feelings; it is applied to reduce the addressee's pain, to show sympathy with the hearer. Deploring is used in such cases as telling off a naughty child or keeping the hearer informed of his/ her wrongdoings. With respect to lamenting, it is comparable to condoling in communicating depression; nevertheless, lamenting is targeted at the speaker's own mishap. As regards welcoming, its social purpose is to indicate delight in one's appearance, to consider the arrival a favor. In terms of forgiving, its role is to show acceptance to an apology, and to put an end to the matter. Last but not least, the act of boasting, it involves the speaker's pride in past achievements, to impress others, and to deter someone from competing or resisting.

\section{Methodology}

\subsection{Data sources and Samples}

The data of the study were the expressives gathered from the judges' commentaries in the TV shows, The Voice UK Season 7 and The Voice Vietnam Season 5. Both of the shows were taken place and on air in the two countries in 2018. As these programs belong to the socalled talent-seeking and entertainment ones, the frequency of expressive acts is likely to be higher than that of other speech acts. The number of the expressives of the whole series, encompassing many rounds, was quite large. Therefore, only those from the last two rounds, semi-final and final rounds, were chosen. And it seemed that the comments in the two selected rounds were more detailed with shrewd expressives. The parts of judges' remarks were included at the end of the candidates' performances, downloaded from the YouTube channels of the two reality shows.

To distill the expressives from the commentaries, the framework of expressive speech act suggested by Norrick (1978, pp. 284-291) was adopted. The Norrick's taxonomy can be regarded as a comprehensive classification of expressive speech acts; it clarifies and develops the primary types of expressive speech acts suggested by Searl (1976, p.12), which were illustrated by such expressive verbs as thank, congratulate, apologize, condole, deplore, and welcome. Beacuse of its comprehensiveness, this classification proves beneficial to the approach of this study, although not all the expressives collected can be covered by this categorization, and many Norrick's categories were not found in the commentaries.

Basing on the taxonomy of expressives by Norrick (1978) and the expressives found in the research process, the expressives can be 
grouped into the sets of apologizing, thanking, congratulating, condoling, deploring, lamenting, welcoming, forgiving, boasting, complimenting, liking, bidding, and others.

It can be argued that the bidding indicates ideals that the speaker clings to may not completely correspond to the current state of affairs. Liking refers to the groups of expressives which are realized by the use of such verbs as like, love, hate, dislike, ... The group others covers the expressives commonly triggered by the adjectives, such as happy, proud, emotional, ... The set of complimenting sometimes overlaps with that of congratulating; however, the subtle difference exists between these two groups in some instances.

It should be conceded that in English and Vietnamse, almost all of the expressive acts are used; however, the modes of actualizing these acts in the two languages are different to some extent due to the variance of the morphological and syntactic features. Nevertheless, the two groups of judges shared the similarity concerning the use of indirect instead of direct indication of expressive acts. As a result, in order to define the types of expressives, attention also should be paid to reading the entire utterance, not just individual words or phrases.

Table 3 illustrates the number of expressive speech acts gathered as data in the two shows.

Table 3. Types of expressives in the study

\begin{tabular}{|c|c|c|c|c|}
\hline \multirow{2}{*}{ Expressives } & \multicolumn{2}{|c|}{ The Voice UK 2018 (EUJs) } & \multicolumn{2}{c|}{$\begin{array}{c}\text { Voice VN 2018 } \\
\text { (EVJs) }\end{array}$} \\
\cline { 2 - 5 } & Instances & Percentages & Instances & Percentages \\
\hline Apologizing & 0 & $0 \%$ & 0 & $0 \%$ \\
\hline Thanking & 0 & $0 \%$ & 9 & $5.1 \%$ \\
\hline Congratulating & 50 & $28.1 \%$ & 42 & $23.9 \%$ \\
\hline Complimenting & 62 & $34.8 \%$ & 40 & $22.7 \%$ \\
\hline Condoling & 10 & $5.6 \%$ & 16 & $9.1 \%$ \\
\hline Deploring & 0 & $0 \%$ & 4 & $2.3 \%$ \\
\hline Lamenting & 1 & $0.6 \%$ & 2 & $1.1 \%$ \\
\hline Welcoming & 0 & $0 \%$ & 0 & $0 \%$ \\
\hline Forgiving & 0 & $0 \%$ & 1 & $0.6 \%$ \\
\hline Boasting & 0 & $0 \%$ & 0 & $0 \%$ \\
\hline Bidding & 7 & $3.9 \%$ & 21 & $11.9 \%$ \\
\hline Liking & 14 & $7.9 \%$ & 11 & $6.3 \%$ \\
\hline Others & 34 & $19.1 \%$ & 30 & $17 \%$ \\
\hline TOTAL & $\mathbf{1 7 8}$ & $\mathbf{1 0 0 \%}$ & $\mathbf{1 7 6}$ & $\mathbf{1 0 0 \%}$ \\
\hline
\end{tabular}

\subsection{Data analysis}

The sub-system of Affect in Appraisal theory was used as the theoretical framework for the procedure of data analysis. With the corpora of 178 EUJs and 176 EVJs, the Affect resources wielded in the expressives in the two languages were positioned, sorted out regarding typology (In/Security, Un/Happiness, Dis/ Satisfaction, Dis/Inclination), polarity (positive or negative) and strategy (inscribed/explicit or invoked/implicit). The EUJs were numbered from E1 to En and EVJs from V1 to Vn. 
The data were imported to the computer with the software Microsoft Office Excel. With the assistance of this tool, the frequency, as well as the proportion of each class, would be precisely calculated.

The data exported from the computer were summarized, presented in tables, and described using descriptive techniques. Thereby, comparative and contrastive tactics were utilized to disclose the resemblances and distinctions as concerns the manipulation of Affect resources of the judges in the two countries.

Apartfrom that, the background knowledge of culture and linguistics would also prove productive, aiding the author in providing essential justification for the statistical analysis, particularly for the similarities and dissimilarities of the utilization of language for the evaluative purpose of the UK's and the Vietnamese judges.

\section{Findings and Discussion}

\subsection{Affect resources in EUJS}

\subsubsection{Four sub-types of Affect resources in EUJ}

Table 4. Four sub-types of Affect in EUJs

\begin{tabular}{|c|c|c|}
\hline Sub-types of Affect resources in EUJs & Instances & Rate \\
\hline Dis/Inclination & 4 & $5.2 \%$ \\
\hline Un/Happiness & 51 & $66.2 \%$ \\
\hline In/Security & 8 & $10.4 \%$ \\
\hline Dis/Satisfaction & 14 & $18.2 \%$ \\
\hline Total & $\mathbf{7 7}$ & $\mathbf{1 0 0 \%}$ \\
\hline
\end{tabular}

As can be seen from Table 4, Un/Happiness was the most common Affect value in the expressives by the UK's judges, ranking first with $66.2 \%$. Dis/Satisfaction accounted for the second highest rate (18.2\%), and the third rank was In/Security (10.4\%). Dis/Inclination was the least common among the four sub-types of Affect, with only 4 out of 76 resources falling into this category. The following extracts are given as examples of the four types of Affect in EUJs found in the data.

[E1] I love you!

[E2] love it love it love it love it!

[E3] Oh I like it, says 'Whoo'... like the energy of it, the chant I put along

[E4] what I love most is how you took your own liberties
[E5] I felt the joy in it

[E6] We all love you

[E7] And I have to be honest, even though I'm rooting for Donel I can't help but love your voice.

The judges of The Voice UK employed the words love, like, joy in a comprehensive manner to express their affection and cheer towards the candidates and their performances. Besides, the word amazing was also wielded by the EUJs to indirectly express the emotion of great excitement, as illustrated in the following examples,

[E8] I mean that was amazing in more ways than one. That was amazing.

[E9] You're just born...you are born to do what you're doing, and you're just you're amazing 
[E10] Yes!!! Lord!! It's amazing.

[E11] You are amazing... you are amazing, really!

[E12] this show is about the voice, and it's amazing.

[E13] your world is so amazing

[E14] on paper that song just shouldn't work you know what I mean but Tai, you did your thing on it, and it was just amazing

The UK's judges also showed their contentment in the candidates' performances by using the Dis/Satisfaction value. The satisfaction feeling in EUJs was mostly realized by the adjective proud. For instance,

[E15] We're very proud of you!

[E16] and I'm proud of you for that!

[E17] I'm so proud!

[E18] I'm so proud of you, Lauren, honestly

[E19] we're all proud parents in a way because we have like the people that we are rooting for

The Dis/Inclination and In/Security were less usual than the other two values. By resorting to the Dis/Inclination, the UK's judges convey their desire of the candidates making progress to head for the later rounds and gaining more success after leaving the contest. As a result, the verbs hope and want proved useful in these cases. This was presented by the examples [E20], [E21], and [E22]. By the utilization of the In/Security value, the judges in The Voice UK indicated their confidence and determination. They thought that based on the present capacity, the candidates would undoubtedly move further and achieve fruitful results in the future, such as securing a slot in the final round or becoming colleagues of their coaches, creating many hits after the game. This was vividly illustrated by the instances of [E23], [E24], and [E25].

[E20] and I just hope you make the final, mate. I really do.

[E21] and it made us all want to celebrate and be a part of it with you

[E22] I...I really want to see you guys out there doing what you're doing and have a huge success

[E23] Yes, you sang 'I'm alive, 'right? I'm alive; I believe you if nobody believes you after that.

[E24] You need to be in that final without a shadow of a doubt. You need to be there. You have to.

[E25] I'm gonna see you in the charts. I have no doubt that me and you will be in the charts battling against each other. No doubt!

\subsubsection{Authorial and Non-authorial Affect} resources in EUJS

Emotions can be Authorial or NonAuthorial (White, 2015b). Authorial Affect deals with the agents' emotional responses while Non-authorial is concerned with the feelings of other people that are observed and reported by the agents. Figure 2 depicts the distribution of the Authorial and Nonauthorial Affect in EUJs.

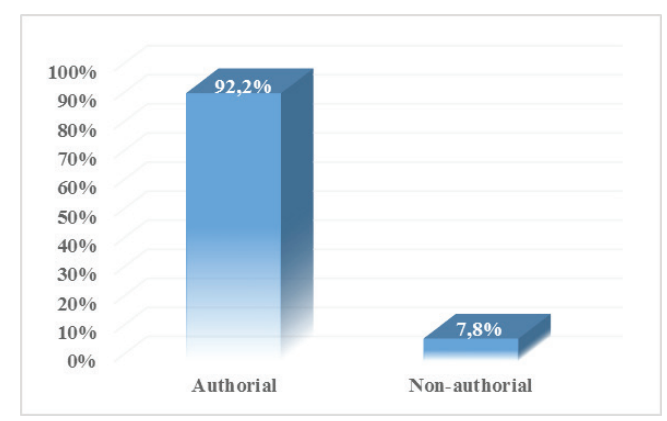

Figure 2. Authorial and Non-authorial Affect in EUJs 
It is apparent from Figure 2 that most of all the Affect resources in EUJs were of Authorial ones, amounting to over $90 \%$ of the total number of Affect, whereas only 6 out of 77 Affect resources were about the feelings observed by the judges. The Nonauthorial Affect resources were employed mainly to show the judges' sympathy with the difficulties or hardships that the candidates had to overcome. By doing so, the judges aspired to give essential mental support or encouragement to the contestants. [E26], [E27], [E28], [E29], [E30], [E31] are typical cases of Non-authorial Affect in EUJs,

[E26] Honestly! I know how nervous you were tonight

[E27] it looked like it was giving you confidence because you were right in it

[E28] So you're gonna look back at this, and you're gonna be very proud of yourself like we are

[E29] You know, you're a little unsure when when I suggested the song

[E30] 'Cause I could feel you're getting quite emotional.

[E31] I know how nervous you must have been doing it

\subsubsection{Positive and Negative Affect} resources in EUJS

In this part, Affect resources are examined concerning the polarity (positive or negative). Under Affect, we are interested in considering emotions, with positive responses and negative responses and dispositions. Positive sentiments are concerned with jubilance, self-assurance, attentiveness, etc., whereas negative emotions touch on depression, apprehension, nuisance, etc.

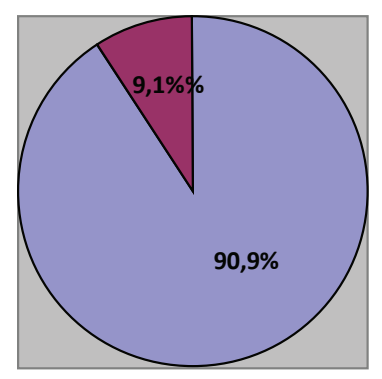

$\square$ Positive

$\square$ Negative

Figure 3. Positive and Negative Affect resources in EUJs

Figure 3 reveals that most of the Affect resources in EUJs are positive, constituting over $90 \%$, and around $9 \%$ is the percentage of negative emotions. Typical examples of negative responses are presented as follows,

[E32] Honestly! I know how nervous you were tonight

[E33] You know, you're a little unsure when... when I suggested the song

[E34] it's a very powerful scary piece of music

[E35] I know how nervous you must have been doing it

The exemplars indicate that the Negative Affect was exploited just for the reason of showing the feeling of disquiet of the candidates when being assigned the song or when performing on the stage. Also, the Negative Affect resources were adopted to show the judges' own feelings of disappointment. For instance,

[E36] You snatched all ponytails, and we don't even have one, first of all

[E37] Tom just took me out of those feelings! 


\subsubsection{Inscribed and Invoked Affect resources in EUJS}

Table 5. Inscribed and Invoked Affect in EUJs

\begin{tabular}{|c|c|c|}
\hline Affect resources in EUJs & Instances & Rate \\
\hline Inscribed & 30 & $39 \%$ \\
\hline Invoked & 47 & $61 \%$ \\
\hline Total & $\mathbf{7 7}$ & $\mathbf{1 0 0 \%}$ \\
\hline
\end{tabular}

Affect resources can be realized directly or indirectly. In other words, they can be Inscribed or Invoked. As is observed from Table 5, most of the Affect resources in EUJs were Invoked Affect, occupying around $60 \%$. The typical cases of Invoked Affect were those containing the words amazing, stunning or the expressions blown away/blow me away, got goosebumps all over which indirectly highlight the emotion of excitement or surprise, as in [E38], [E39] [E40], [E41], [E42]. The Invoked Affect also expressed the judges' feelings of admiration or satisfaction as in [E43], [E44] or [E45]. The Invoked Affect could be realized by not only individual words, but also by phrases, or even the whole sentences, or a group of sentences.

[E38] I mean that was amazing in more ways than one. That was amazing.

[E39] Actually that was stunning

[E40] Every time... every time I see you lose you just blow me away

[E41] I'm blown away

[E42] this week I just got goosebumps all over, honestly. I mean I can't show you but all over goosebumps
[E43] I went for opera event not too long ago, and when I finished singing they said, Brava! Brava! Brava! So, brava! Brava!

[E44] hats off to you guys

[E45] Oh my god! I'm always a fan of his

In the example [E43], brava! in this context can be considered as an equivalent of congratulations. Through the act of congratulating, the judge revealed his/her satisfaction towards the performance. In the similar vein, the expression hats off to you in [E44] demonstrated the feeling of admiration or respect of the judges for impression brought about by the candidate. The emotion of admiration was also highlighted by the employment of the word fan in [E45].

\subsection{Affect resources in EVJS}

This section focuses on examining Affect resources in EVJs, laying the foundation for the comparison and contrast with the Affect resources in EUJs, which have just been discussed in the previous parts.

\subsubsection{Four sub-types of Affect resources in} EVJS

Table 6. Four sub-types of Affect resources in EVJs

\begin{tabular}{|c|c|c|}
\hline Sub-types of Affect in EVJs & Instances & Rate \\
\hline Dis/Inclination & 8 & $9.6 \%$ \\
\hline Un/Happiness & 25 & $30.1 \%$ \\
\hline In/Security & 12 & $14.5 \%$ \\
\hline Dis/Satisfaction & 38 & $45.8 \%$ \\
\hline Total & $\mathbf{8 3}$ & $\mathbf{1 0 0 \%}$ \\
\hline
\end{tabular}


As indicated in Table 6, in EVJs, Dis/ Satisfaction and Un/Happiness resources constituted higher proportions than the other two, occupying about $46 \%$ and $30 \%$ respectively. The In/Security came next, with just above half of the percentage of $U n /$ Happiness, at around 15\%. The research also registered the occurrence of Dis/Inclination value, but it stood at a rate of just under $10 \%$. All four dimensions of Affect resources are demonstrated through the following representative cases.

The Affect resources of Dis/Satisfaction were mainly realized by the word tur hào (proud) to express his/her pride and contentedness in their students' performances, which lived up to their expectation.

[V1] Ngày hôm nay chị thực sụ rất là tụ hào về Thái Bình

(I'm so proud of Thai Binh today)

[V2] Anh rất tụ hào về em

(I'm so proud)

[V3] Anh cảm thấy rất là tụ hào

(Ifeel so proud)

[V4] Anh rất tụ hào vì em đã tin tưởng anh, cùng làm nên một Gia Nghi trưởng thành nhu ngày hôm nay

(I feel proud as you trust me, becoming more mature now)

[V5] Em làm anh rất tụ hào, Nghi à.

(You make me so proud, Nghi)

[V6] Anh rất tự hào về em Ánh à

(I'm very proud of you, Anh)

[V7] Và chị muốn khoe năm bạn ở đây với khán giả ở đây và khán giả đang xem trục tiếp truyền hình đó là, bọn chị cực kì tụ hào về năm bạn ở đây
(I wanna praise five of you in front of the audience, we, as coaches, are extremely proud of you)

The Vietnamese judges gave vent to their emotions of Un/Happiness, especially Affection and Cheer through the use of such words as thich, yêu, hạnh phúc, phấn khích, suớng/sung suoóng/sướng lỗ tai (like, love, elated, gratified)

[V8] Có lẽ là tất cả HLV, đồng nghiệp của anh sẽ có rất nhiều điều về chuyên môn, nhưng anh hiện giờ trong lòng anh chì là cảm xúc rất là sung sướng mà thôi

(The coaches, my colleagues probably share many specialized things, but it's the delight I can sense now)

[V9] Hôm nay anh đến và được ngồi nghe các em hát, cảm thấy sướng lỗ tai, sướng lắm

(Listening to your performances, I am so gratified, really)

[V10] Anh rất là phấn khích bởi vì hôm nay, đây là ngày cuối cùng chúng ta bước vào chặng cuối của cuộc thi Giọng hát Việt năm 2018

(I'm elated as this is the last day of the final rounds of The Voice 2018)

[V11] Chị thích em ở màu sắc này hơn bởi vì nó thể hiện rõ nội lực trong giọng hát em.

(I like it when you're with this form as it clearly shows the inner strength of your voice)

[V12] Anh rất thích các tiết muc của Giọng hát Việt năm nay

(I really enjoy the performances of this season)

[V13] Chị luôn luôn yêu em, vậy thôi.

(I always love you, that's all)

[V14] Anh rất là hạnh phúc

(I'm so happy) 
The In/Security were actualized mainly by the manipulation of the word tin (believe) to convey the emotion of strong belief and the judges' degree of certainty in giving opinions, whereas the word thänh thoi (leisurely) was put to use in order to describe the coaches' trust in the capacity of their students. In other words, the judges did not need to worry much about their contestants' performances.

[V15] Chị tin là nhu thế

(I believe so)

[V16] Và chị tin là Noo Phuớc Thịnh đang hãnh diện thật vì nhũng gì mà em đang làm được.

(And I believe that Noo Phuoc Thinh is proud of what you're doing.)

[V17] Em thảnh thơi em ngồi xem.

(I watch it leisurely)

[V18] Tiên tin rằng tâm thế của bốn HLV ở đây đêm nay là đến đây để theo dõi, để thường thi̛c phần trình diễn của năm bạn thí $\sinh$

(Tien believes that the four coaches' mind here tonight is coming here to watch, to enjoy the performance of the five contestants.)

[V19] Và chị tin rằng nếu nhu nhũng cố gắng của các em, nhũ̃ng nỗ lực của các em và nhũng gì HLV của các em đang cố gắng dành cho các em, hi vong các em sẽ thành công.

(And I believe that with all your efforts, the coaches' efforts, I hope you will succeed.)

As regards the Affect resources of Dis/ Inclination in EVJs, the Vietnamese judges voiced the ideals they had for the candidates. They opted for such words as hi vong, muốn, mong, trông đơi (hope, want, expect). By way of illustration,
[V20] Anh muốn cho Alex ở vòng này có một sự thay đổi so với vòng trước

(I want Alex to have a change from the previous round)

[V21] Đây đúng là Ánh mà chị trông đọi.

(This is precisely what I've expected from Anh)

[V22] Chị hi vọng khán giả sẽ có cái nhìn, cũng nhu là sụ yêu thưong nhất định để vote cho các em, ai sẽ là người xúng đáng nhất đêm nay

(I hope the audience will have their own decisions, as well as their own interests, to vote for the most worthy person tonight)

[V23] Và chị mong rằng các em sẽ thành công hơn nũa trong phần hai của đêm nay

(And I expect that you will be even more successful in the second part of the night)

4.2.2. Authorial and Non-authorial Affect resources in $E V J_{S}$

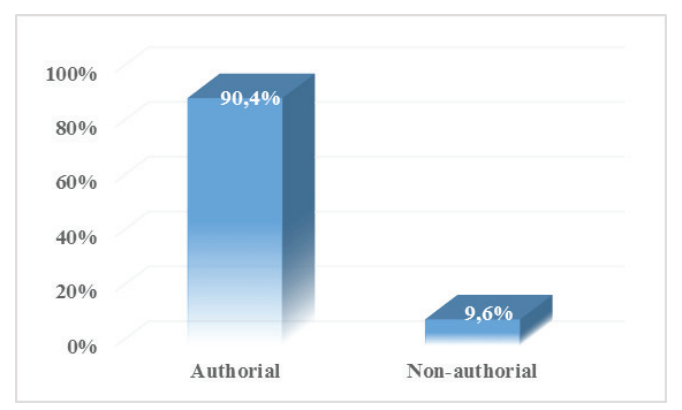

Figure 4. Authorial and Non-authorial Affect in EVJs

Figure 4 compares the proportion of Authorial Affect resources and Non-authorial ones. The Authorial Affect resources played the dominant role, with over 75 out of 83 Affect resources. The Non-authorial Affect in EVJs was exemplified through the following instances, 
[V24] Anh biết tất cả các em cũng như các HLV ở đây, chúng tôi đều có một sự tiếc nuối ơ trong lòng rất là lớn

(I know all of you as well as the coaches here, we all have a huge regret in our hearts.)

[V25] Em tức với chính bản thân mình

(You're angry with yourself)

[V26] Đây là nhũng điều mà thực sụ tù̀ đầu em rất là thích

(These are the things that you're really into from the beginning)

[V27] Ngày hôm nay chị thấy cảm xúc của em rất là dâng trào và chị nghĩ hình nhu cũng có lúc Ánh hoi là nghẹn ngào, hơi nức nở một tí xíu

(Today I feel your emotions are very intense and it seems you're a little choking, a little sobbing.)

[V28] Em có thể hoàn toàn tụ tin

(You can be completely confident)

[V29] đó là với sụ cố vấn tì anh Lam Truờng thì không có việc gì phải sọ cả.

(with the advice from Lam Truong, there is nothing to be afraid of)

[V30] Thực ra thì Bình có một nỗi sọ; một nỗi sợ rất là bình thuờng đối với một cô nàng 19 tuổi.

(Actually, Binh has a fear, a common fear for a 19-year-old girl)

Although the Non-authorial occupied a small percentage in the EVJs, they played an essential role in terms of psychology. They served to help the coaches to express their great sympathy and care for the contestants. Indeed, the judges implied that they understood all the feelings that the performers experienced, no matter how good or bad they were, which results in prompting the candidates to try their hardest for the later rounds.

\subsubsection{Positive and Negative Affect} resources in EVJ

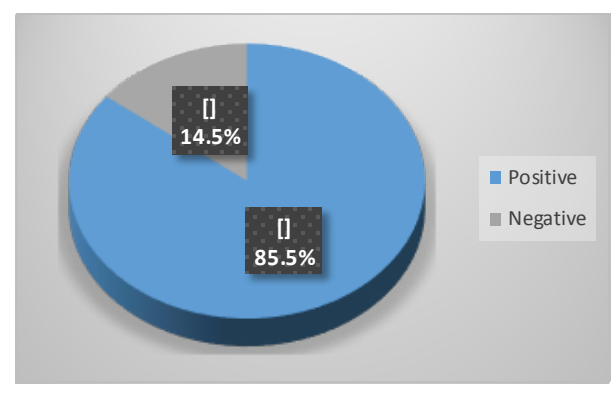

Figure 5. Positive and Negative Affect resources in EVJs

Figure 5 reveals that the Vietnamese judges preferred to offer positive evaluations in terms of sentiments, with $85.5 \%$ of Affect resources at the positive polar. The Negative Affect resources in EVJs chiefly denoted the pity or regret they experienced on parting, or at times they hinted at the apprehension or jealousy. The words buồn, luyến tiếc, ghen tị, nức nở, nghẹn ngào, tức, lăn tăn (sad, regretful, jealous, sobbing, choking, angry, worried) were employed in a very clever manner to portray all delicate negative emotions.

[V31] Cảm giác của Phuoong có một chút, tất nhiên là buồn, bởi vì mình luyến tiếc vì các hoc trò của mình không có co hộ ở trên sân khấu ngày hôm nay để thể hiện khả năng của các em. Đó là điều mà luyến tiếc đối với Thu Phưong

(I feel a bit, of course, sad, because I'm regretful that my students don't have the opportunity to be on stage today to show their abilities. That is a regret for me)

[V32] Anh biết tất cả các em cũng nhu các HLV ở đây, chúng tôi đều có một sụ tiếc nuối ơ trong lòng rất là lón

(I know all of you as well as the coaches here, we all have a huge regret in our hearts.) 
[V33] Noo nhớ lại những ngày đầu đi cùng Giọng hát Việt, Noo đã lăn tăn rất là nhiều, có nhiều sự đấu tranh ở trong Noo, không biết là có nên ngồi một mùa Giọng hát Việt nữa không

(I remember the early days with The Voice, I was freaked out a lot, there was a lot of struggle in me, not knowing whether to join another season.)

[V34] Em tức với chính bản thân mình

(You're angry with yourself)

[V35] Ngày hôm nay chị thấy cảm xúc của em rất là dâng trào và chị nghĩ hình nhu cũng có lúc Ánh hơ là nghẹn ngào, hơi nức nở một tí xíu
(Today I feel your emotions are very intense and it seems a little choking, a little sobbing.)

[V36] Ngoài chuyện mình rất vui, rất tụ hào về tất cả top 7 hôm nay thì còn có một sụ ghen tị nho nhỏ, đó là năm nay các bạn thí sinh The Voice đều được ư ái, bạn nào cũng có một bài hát riêng

(Apart from being very happy, being very proud of all the top 7 today, I'm a little jealous, because this year all the contestants of The Voice are favored, everyone has a single.)

\subsubsection{Inscribed and Invoked Affect} resources in $E V J$

Table 7. Inscribed and Invoked Affect resources in EVJs

\begin{tabular}{|c|c|c|}
\hline Affect resources in EVJs & Instances & Rate \\
\hline Inscribed & 34 & $41 \%$ \\
\hline Invoked & 49 & $59 \%$ \\
\hline Total & $\mathbf{8 3}$ & $\mathbf{1 0 0 \%}$ \\
\hline
\end{tabular}

In terms of strategy, the Affect resources in EVJs were invoked more commonly than inscribed or directly stated. Indeed, as seen from Table 7, approximately $60 \%$ of Affect resources in EVJs were indirectly realized through many different forms. The most striking cases were those where the judges congratulate, express gratitude towards the contestants, with the verb chúc mùng, cảm on (congratulate, thank). It can be argued that this activity invoked the emotion of satisfaction. To illustrate,

\section{[V37] Chúc mùng em}

(Congratulations)

[V38] Chúc mùng Ngân đã có một phần trình diến rất thành công ngày hôm nay.

(Congratulations on having a very successful performance today.)

[V39] Và Minh Ngoc ã̃ thay lời cho Noo truyền tải thông điệp đến tất cả mọi người qua ca khúc "Bóng mây qua thềm."

(And Minh Ngoc helps Noo to convey the message to everyone through the song.)

[V40] Chúc mùng Minh Ngọc với phần thể hiện vì̀a rồi

(Congratulations on your performance)

[V41] Chị cảm ơn Luu Hiền Trinh đã hoàn thành tốt nhiệm vu này.

\section{(Thank you for fulfilling this task.)}

In the example [V39], by utilizing the phrase đã thay lơi cho Noo (on behalf of Noo), the judge aspired to express his contentment as the his candidate achieved the expected purpose of transmitting the message to the audience through the peformance.

Apart from those examples, the instances with the word tụ hào (proud) also conjured up the meaning of satisfaction. For example, 
[V42] Anh rất tư hào vì em đã tin tương anh, cùng làm nên một Gia Nghi trương thành nhu ngày hôm nay

(I am very proud because you trust me, becoming more mature today)

[V43] Và chị muốn khoe năm bạn ở đây với khán giả ở đây và khán giả đang xem trục tiếp truyền hình đó là, bọn chị cực kì tự hào về năm bạn ở đây

(And I wanna praise you in front of the audience, we, as coaches, are extremely proud of the top five.)

The following instance indirectly called for the emotion of desire by the word phai chi. (should have done). It is arguable that the judge wanted the performer to make progress by following the suggestions proposed by the judge,

[V44] Chỉ cảm thấy một chút xíu này thôi. Phải chi bớt nhũng đoạn phiêu vocal, thay vào đó bằng một đoạn lắng mà em và các thiên thần nhỏ cùng hát chung thì sẽ làm cho em tù một giong ca nộ lực có một sụ tinh tế hơn nữa và hoà quyện hơn nũa khi mà tất cả moi người ở khán phòng này cùng lắng đọng, cùng nghe, cùng thrởng thưc

(I wanna comment on this. You should have reduced the vocal feels, replaced by a silent period when you and the little angels sing together, which adds subtlety to your inner strength, to be in harmony with everyone in this auditorium, who together settled, listened, enjoyed it)

\subsection{Similarities and differences of Affect resources in EUJS versus EVJS}

This section is devoted to encapsulating the similarities and differences of Affect resources in EUJs versus EVJs.

As far as the four sub-types of Affect resources are concerned, the rate of the four kinds of Affect in EUJs and EVJs followed a similar order pattern, in which Un/Happiness and Dis/Satisfaction accounted for more immense proportions, at $66.2 \%$ and $18.2 \%$ respectively in EUJs and $30.1 \%$ and $45.8 \%$ respectively in EVJs. It can be observed that the value of Dis/Inclination ranked last in both EUJs and EVJs, accounting for 5.2\% and $9.6 \%$ correspondingly.

Besides, there were more Authorial Affect resources than the Non-authorial ones in both of the corpus. However, the Non-Authorial Affect resources had a vital role to play in expressing the judges' sympathy with the hardship experienced and the effort made by the candidates. This, in turn, led to the mutual understanding among them, making the contestants heartened to move forward, try harder for the succeeding rounds.

Turning to the polarity, EUJs and EVJS shared the similarity. It was found that the two groups of judges were in favor of the Positive Affect resources rather than the Negative ones. The Negative emotions were attached to the instances where the judges express the anxiety of the candidates, and their pity resulted from the upcoming farewell.

Concerning the strategy, interestingly, invoking was more frequently adopted than inscribing in both EUJs and EVJs. By invoking the Affect resources, the judges could unveil their emotions more flexibly in several ways, not only directly via certain individual words but also through sentences. Therefore, in [V45], no word of pity was mentioned, but that sentiment could still be inferred from connecting all the lexical items used. For instance,

[V45] Cho đến khoảnh khắc này, ngày mai thôi chúng ta sẽ không còn phải chịu nhũng áp lực này nũa, ngày mai thôi chúng ta sẽ phải chia tay với một sân khấu tuyệt vời nhu thế này

(Until this moment, tomorrow we'll no longer have to bear these pressures, tomorrow we'll have to say goodbye to a beautiful stage like this) 
It was discovered that in EUJs, and EVJs, specific common lexis was brought into play for particular kinds of Affect resources. For instance, the judges avail themselves of like/ thich, love/ yêu, get goosebumps all over/ nổi da gà, ... for Un/Happiness value, proud/ tụ hào for Dis/Satisfaction, believe/no doubt/tin for In/Security, want/muốn, hope/hi vong or mong for Dis/Inclination.

\section{Conclusion and Implications}

As regards Affect, in both EUJs and EVJs, the findings claimed the occurrence of four sub-types of Affect. The Affect resources in the employed by the UK's judges and the Vietnamese ones followed the same ranking pattern of frequency, from the highest to the lowest, as follows: Un/Happiness, Dis/ Satisfaction, In/Security, Dis/Inclination. In these reality shows, the coaches wished to reveal their excitement and satisfaction to other people, mainly when the students performed compellingly. Furthermore, Positive feelings were more popular than the Negative ones. Most of the Affect resources described the judges' own emotions, which brought about the widespread use of Authorial Affect in English and Vietnamese expressives. Besides, the feelings of the judges in Vietnam and the UK were mainly displayed indirectly through the Invoked Affect. For realizing the Affect, certain typical words were adopted, such as like/love/get goosebumps all over/ yêu thích/nổi da gà; proud/tụ hào, believe/tin, want/hope/mong/muốn/hi vọng, etc.

The research results also indicate that there exists a close relationship between the expressive acts in particular and Speech Act Theory in general with Appraisal Theory, especially the Affect aspect of the system of Attitude. While the Speech Act Theory only deals with the range of acts conveyed through the employment of language, the Appraisal Theory plays the supplementary role. Indeed, through the acts of complimenting, congratulating, bidding, liking, etc., the judges would like to offer their evaluations coupled with expressing various kinds of sentiments. Phrased another way, the emotionl aspects detailed by the four sub-types of Affect in Appraisal render the expressive acts more concrete, insightful and intriguing. And the speakers making expressive acts simultaneously fulfill the role of the appraisers.

It is expected that the study can contribute to the research, performance, and interpretation of attitudinal values of Affect from the theoretical and practical perspective. For theoretical value, up to now, many studies have adopted the Appraisal conceptual framework as a tool for analyzing the texts in terms of attitudinal meaning in non-verbal and verbal language. Nevertheless, there has not been any research on the speech act in light of the Appraisal Theory. Thus, the study is a new approach to gain an insight into the features of attitudinal values of Affect conveyed by the expressives in English and Vietnamese.

The current study analyzed the Attitude of the judges' expressives - complimenting, congratulating, condoling, liking, etc., through examining their employment of Affect resources from the perspective of Appraisal Theory. The findings of the study can be of help to language learners in providing them with the knowledge of Appraisal and the characteristics of the evaluative language used by the judges through their expressive speech acts. Since the linguistic resources employed in this study were from authentic sources of communication by the native speakers, this research can be practical for learners of English in applying the language of evaluation not only in the classroom setting but also in their daily communication, thus rendering their communication in English more natural and vivid. By studying the evaluative 
language of the judges, learners are also capable of brushing up on the communication skills in their mother tongue by imitation and practice so that they learn how to say things efficiently and intriguingly to the opposite. Furthermore, learners of Vietnamese can make use of this study as a fruitful reference in studying how language can be used to give assessments in Vietnamese.

\section{References}

Austin, J. L. (1962). How to do things with words. Oxford: Oxford University Press.

Bach, K., \& Harnish, R. M. (1979). Linguistic communication and speech acts. Cambridge: The MIT Press.

Bui, T. X. D. (2018). Transivity in Comments Given by Judges on TV Programs: America's Master-Chef and Vietnam's Master-Chef. Unpublished Master's Thesis. Quy Nhon University.

Guiraud, N., Longin, D., Lorini, E., Pesty, S., \& Rivière, J. (2011). The face of emotions: a logical formalization of expressive speech acts. The 10th International Conference on Autonomous Agents and Multiagent Systems, 3, 1031-1038.

Hadidi, Y., \& Mohammadbagheri-Parvin, L. (2015). Systemic functional linguistics as interpersonal semantics: appraisal and attitude in the stylistic analysis of an English novel. International Journal of Linguistics, 7(1).

Le, H. L. (2019). An Attitudinal Analysis of Expressives by the Judges of The Voice UK versus The Voice Vietnam. Unpublished Master's Thesis. Quy Nhon University.

Le, H. L. (2017). An Attitudinal Analysis of English Letters of Complaint. Unpublished Master's Thesis. Quy Nhon University.

Le, T. V. T. (2017). An Attitudinal Analysis of Barack Obama's Speeches Made in His Visits to Vietnam, Japan, China and Laos in 2016. Unpublished Master thesis. Quy Nhon University.

Li, X. (2016). An attitudinal analysis of English song discourse from the perspective of appraisal theory. Journal of Language Teaching and Research, 7(3), 559-565.

Liu, X. (2013). Evaluation in Chinese University EFL Students' English Argumentative Writing: An APPRAISAL Study. Electronic Journal of Foreign Language Teaching, 10(1). Trang

Martin, J. R., \& Rose, D. (2007). Working with discourse: Meaning beyond the clause (2nd ed.). London: Continuum.

Martin, J. R., \& White, P. R. R. (2005). The language of evaluation. London: Palgrave Macmillan.
Ngo, A. Q. N. (2017). An Investigation into the Attitudinal Resources in English and Vietnamese News about Environment. Unpublished Master's thesis. Quy Nhon University.

Ngo, T., \& Unsworth, L. (2015). Reworking the appraisal framework in ESL research: refining attitude resources. Functional Linguistics, 2(1). doi:10.1186/s40554-015-0013-x.

Ngo, T. (2013). The deployment of the language of evaluation in English and Vietnamese spoken discourse. (Thesis Doctoral), University of New England, Armidale, NSW. Retrieved from https:// hdl.handle.net/1959.11/16973

Nguyen, T. T. (2018). A Contrastive Study of Attitudinal Resources in Comments Given by Judges in "American Idol" and "Vietnam Idol.". Unpublished Master's thesis. Quy Nhon University.

Nguyen, T. L. (2017). A Study on the Attitudinal Resources in English and Vietnamese Travellers, Holiday Reviews. Unpublished Master's Thesis. Quy Nhon University.

Nguyen, T. M. N. (2017). An Appraisal Analysis of Evaluative Language in English Advertising Slogans. Unpublished Master's Thesis. Quy Nhon University.

Nguyen, T. N. (2018). An Investigation into Attitude Resources in English and Vietnamese Love Song Lyrics. Unpublished Master's Thesis. Quy Nhon University.

Nguyen, T. H. (2015). A Contrastive Analysis of Attitudinal Values in Travel Advertisements in English and Vietnamese Unpublished Master's Thesis. Quy Nhon University.

Norrick, N. R. (1978). Expressive illocutionary acts. Journal of Pragmatics, 2(3), 277-291.

Page, R. E. (2003). An analysis of APPRAISAL in childbirth narratives with special consideration of gender and storytelling style. TEXT-THE HAGUE THEN AMSTERDAM THEN BERLIN-, 23(2), 211238.

Phan, T. T. H. (2017). An Attitudinal Meaning Analysis of Film Reviews Written in English and in Vietnamese A Comparative Study. Unpublished Master's Thesis. Quy Nhon University.

Ronan, P. (2015). Categorizing expressive speech acts in the pragmatically annotated SPICE Ireland corpus. ICAME Journal, 39(1), 25-45.

Ruo-mei, W. A. N. G. (2016). A Practical Application of Appraisal Theory on Critical Reading in College English Teaching. US-China Foreign Language, 14(12), 868-876. doi:10.17265/15398080/2016.12.007

Searle, J. R. (1976). A classification of illocutionary acts. Language in society, 5(1), 1-23.

Tran, T. T. H. (2018). Language of evaluation by judges on reality television in some Vietnamese 
entertaining programs (with reference to English). (Doctoral thesis), University of Social Sciences and Humanities, Vietnam National University, Hanoi.

Tran, T. T. T. (2017). A Study on the Attitudinal Resources in Donald Trump and Hillary Clinton's Speeches in the US Presidential Election 2016. Unpublished Master's Thesis. Quy Nhon University.

Vo, D. D. (2011). Style, structure and ideology in English and Vietnamese business hard news reporting: a comparative study. (Doctoral thesis), The University of Adelaide, Australia. Retrieved from http://hdl. handle.net/2440/71002

Vo, D. D. (2017). Appraisal - an approach to discourse analysis. Inquiry into Languages and Cultures, 1(1), 13-24.

Vo, T. K. T. (2017). An Attitudinal Study of Readers' Opinions in English and Vietnamese Newspapers. Unpublished Master's Thesis. Quy Nhon University.

Vo, T. N. H. (2014). Attitude in Victory Speeches of Barack Obama and George Walker Bush. Unpublished Master's Thesis. Quy Nhon University.
Vo, T. N. (2017). A Contrastive Study of Linguistic Features of Expressive in Comments Given by Judges in America's Got Talents versus Vietnam's Got Talents. Unpublished Master's Thesis. Quy Nhon University.

White, P. R. R. (2015a). Appraisal Theory. In K. Tracy, C. Ilie, \& T. Sandel (Eds.), The International Encyclopedia of Language and Social Interaction (Vol. 3, pp. 1-7): John Wiley \& Sons.

White, P. R. R. (2015b). The Appraisal Website. Retrieved from https:/www.grammatics.com/ appraisal/appraisalguide/unframed/stage1-attitudeaffect.htm

Yule, G. (1996). Pragmatics. Oxford: Oxford University Press.

Zhang, Y. (2018). Attitudinal Analysis of President Xi's Remarks at Press Conference of BRICS Xiamen Summit from the Perspective of Appraisal Theory. Journal of Language Teaching and Research, 9(2), 385-390.

\title{
ĐÁNH GIÁ CẢM XÚC THÔNG QUA HÀNH VI BIỂU CẢM CỦA GIÁM KHẢO THE VOICE UK SO VỚI THE VOICE VIETNAM
}

\author{
Nguyễn Quang Ngoạn, Lê Hữu Lộc \\ Khoa Ngoại ngũ, Trưòng Đại học Quy Nhon \\ 170 An Dưong Vưong, Quy Nhơn, Bình Định, Việt Nam
}

Tóm tắt: Lý thuyết đánh giá (Appraisal Theory) của Martin và White (2005) ngày càng khẳng định vai trò quan trọng trong các nghiên cứu phân tích diễn ngôn, nhằm nêu bật sự đánh giá về thái độ của người nói, người viết đối với một chủ thể, sự vật, sự việc hoặc hành vi nào đó. Nghiên cứu này ứng dụng lý thuyết đánh giá để nhận diện và luận giải đánh giá cảm xúc thông qua hành vi biểu cảm của giám khảo hai chương trình thực tế, The Voice UK so với The Voice Vietnam. Cụ thể, nghiên cứu tập trung tìm hiểu những loại giá trị đánh giá cảm xúc được sử dụng trong các hành vi biểu cảm và chỉ ra điểm tương đồng và dị biệt trong cách áp dụng nguồn ngôn liệu đánh giá cảm xúc thông qua hành vi biểu cảm của hai nhóm giám khảo. Kết quả nghiên cứu ghi nhận sự xuất hiện của tất cả các loại giá trị thể hiện cảm xúc ở cả hai nguồn dữ liệu. Bên cạnh đó, việc sử dụng nguồn ngôn liệu cảm xúc ở hai ngôn ngữ bộc lộ nhiều điểm tương đồng, xét về bình diện tần suất xuất hiện, cách thức và thái cực biểu đạt. Nghiên cứu hi vọng sẽ là nguồn tham khảo bổ ích đối với người học Tiếng Anh cũng nhu Tiếng Việt trong việc đưa ra đánh giá nhận xét trong ngôn ngữ giao tiếp thường ngày.

Tù khoá: Thuyết đánh giá, đánh giá cảm xúc, thái độ, hành vi biểu cảm, giám khảo 